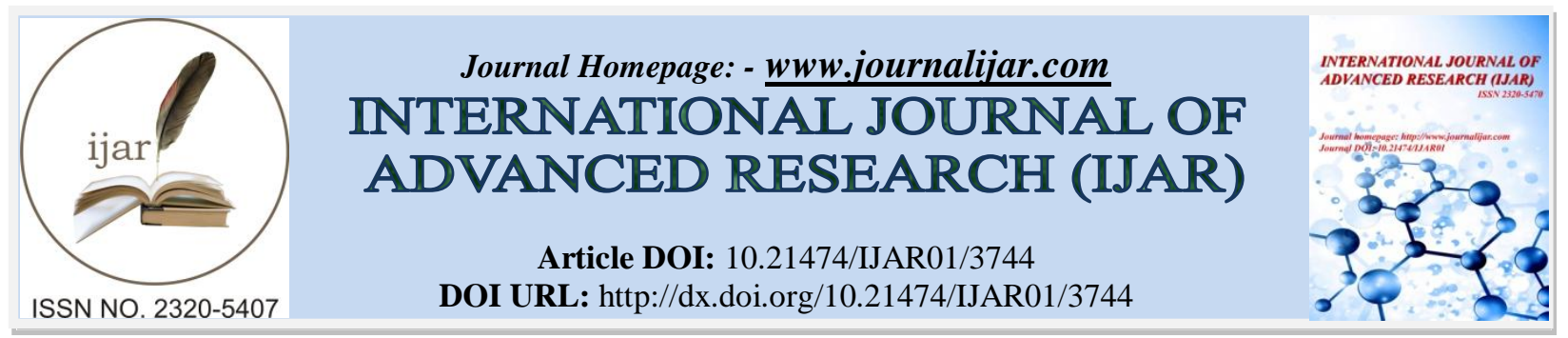

RESEARCH ARTICLE

\title{
STUDY ON POPULATION BUILDS UP OF RICE LEAF FOLDER Cnaphalocrocis medinalis (Guenee) IN RELATION TO WEATHER PARAMETERS.
}

S. N. Gajjar, M. B. Patel and Abhishek shukla.

Department of Entomology, N.M.College of Agriculture, Navsari Agricultural University, Navsari-396450 (Gujarat).

\section{Manuscript Info}

\section{Manuscript History}

Received: 15 January 2017

Final Accepted: 19 February 2017

Published: March 2017

Key words:-

Cnaphalocrocis medinalis, Population build up, weather parameters.

\section{Abstract}

Study on population build up of rice leaf folder Cnaphalocrocis medinalis (Guenee) was carried out at NARP Farm, Navsari Agricultural University, Navsari during Kharif 2012 and 2013.The observation on per cent damaged leaves was recorded immediately after transplanting up to the harvest of the crop. Results shows that maximum 21.9 per cent damaged leaves were observed during fourth week of July (30th SMW) and that of minimum ( 0.2 per cent) were in fourth week of October (43rd SMW). In the present investigation, per cent damage leaves showed significant and positive correlation with morning relative humidity, evening relative humidity, average relative humidity and rainfall but significant negative correlation with maximum temperature, sunshine hours and evaporation rate.

Copy Right, IJAR, 2017,. All rights reserved.

\section{Introduction:-}

Rice (Oryza sativa, Linnaeus.) is a staple food of Southeast Asian population. (FAO, 2004; Kumar, et al, 2009). Global rice production must increase by $36 \%$ by 2025 to feed estimated 4 billion rice consumers (Anderson et al., 1997). But the rice production is limited by both biotic and abiotic stresses of which insect pests alone caused about $25 \%$ losses amounting to Rs.240,138 million (Dhaliwal et al.,2007). Bautista et al., (1984) have clearly shown that loss in yield, due to the rice leaf folder, is positively related to the percentage of damaged leaves. Weather factors are the major regulating causes for the insect pest populations under field circumstances. Certain limits support and other disfavour their multiplication and movement; therefore, it results in serious outbreaks of different insect pests (Hyslops, 1941). Insects are mostly dependent on the environmental temperature for the maintenance of their activity.

\section{Materials and Methods:-}

In order to study the influence of weather parameters on population build up of rice leaf folder Cnaphalocrocis medinalis Guenee experiment was carried out at N.A.R.P. Farm, N.A.U., Navsari during Kharif 2012 and 2013 in $1000 \mathrm{~m} 2$ area in GR 11 rice variety was transplanted with $20 \times 15 \mathrm{~cm} 2$ spacing. All the post sowing recommended agronomical practices were followed. The experimental area was kept free from insecticide spray throughout the crop season in order to record incidence of rice leaf folder C. medinalis. The observations on per cent damaged leaves caused by rice leaf folder $\mathrm{C}$. medinalis were recorded at weekly interval in each standard meteorological week immediately after transplanting up to the harvest of the crop. The leaf folder incidence was assessed by calculating per cent damaged leaves per 10 hills.

Corresponding Author:- S. N. Gajjar.

Address:- Department of Entomology, N. M. College of Agriculture, Navsari Agricultural University, 


\section{Results and Discussion:-}

The data on incidence of rice leaf folder in terms of per cent damaged leaves (DL) per ten hills during kharif-2012, 2013 and pooled were found significant. During Kharif 2012, data recorded on per cent damaged leaves indicated that infestation was ranged from 1.04 to 20.72 per cent. the average infestation started appearing just after establishment of transplanted paddy seedlings i.e. from third week of July [30th SMW] and continued up to the second week of October (41th SMW). The maximum infestation 20.72 per cent DL was found in first week of September (36th SMW).

During Kharif 2013, infestation commences from fourth week of July (31st SMW) and continued up to the fourth week of October (43rd SMW). The maximum infestation (35.96 per cent DL) was found in second week of July. In 4th week of September 39th STW sudden increase in per cent leaf folder damage thereafter started declining up to 4 th week of November (42nd SMW) which noticed minimum 1.44 per cent (DL) and no incidence in next SMW.

Results on pooled data of (Kharif 2012-2013), indicated that in both the years (Table 1). Maximum infestation 21.9 per cent (DL) was observed in fourth week of July (30th SMW). Minimum infestation of leaf folder 0.2.0 per cent (DL) was noticed during fourth week of October (43rd SMW).

The results on correlation of per cent leaf damaged of rice leaf folder, C .medinalis during Kharif-2012 -2013 and pooled were worked out with weather parameters indicated that during first year morning relative humidity $(\mathrm{X} 4)(\mathrm{r}=$ 0.5749), evening relative humidity (X5) $(\mathrm{r}=0.5409)$ and average relative humidity $(\mathrm{X} 6)(\mathrm{r}=0.5651)$ had highly significant positive correlation and rain fall (X9) $(\mathrm{r}=0.0 .4847)$ had significant positive relationshipwith per cent damage leaves (Y1). The maximum temperature $(\mathrm{X} 1)(\mathrm{r}=-0.7230)$, sunshine hours $(\mathrm{X} 8)(\mathrm{r}=-0.5495)$ and evaporation rate (X10) (-0.7986) had highly significant negative correlation with per cent damage leaves. The minimum temperature $(\mathrm{X} 2)(\mathrm{r}=0.3426)$ showed non-significant positive correlation but wind speed $(\mathrm{X} 7)(\mathrm{r}=-$ 0.0571 ) showed non-significant negatively correlation with per cent damage leaves (Table 2).

Likewise, in the subsequent year (Kharif 2013), per cent damage leaves indicated highly significant positive correlation with wind speed $(X 7)(r=0.5758)$ and rain fall $(X 9)(r=0.5455)$.However, the maximum temperature $(X 1)$ $(\mathrm{r}=-0.6317)$ and evaporation rate $(\mathrm{X} 10)(\mathrm{r}=-0.6416)$ exhibited highly significant negative correlation with damage of leaves. The evening relative humidity $(\mathrm{X} 5)(\mathrm{r}=0.4266)$ and average relative humidity $(\mathrm{X} 6)(\mathrm{r}=0.4234)$ showed significant positive correlation but Average temperature (X3) $(r=-0.4265)$ and sunshine $(X 8)(r=-0.4525)$ showed non-significant negative correlation while minimum temperature (X3) ( $\mathrm{r}=0.2928)$ and morning relative humidity (X4) $(r=0.3832)$ had non-significant positive correlation with per cent damage leaves (Table 6.1).

In pooled analysis, overall per cent damaged leaves(Y1) showed significant positive correlation with morning relative humidity $(\mathrm{X} 4)(\mathrm{r}=0.5170)$, evening relative humidity $(\mathrm{X} 5)(\mathrm{r}=0.5083)$, average relative humidity $(\mathrm{X} 6)(\mathrm{r}=0.5114)$ and rainfall $(\mathrm{X} 9)(\mathrm{r}=0.4554)$. The maximum temperature $(\mathrm{X} 1)(\mathrm{r}=-0.7130)$, sunshine hours $(\mathrm{X} 8)(\mathrm{r}=-0.5626)$ and evaporation rate $(\mathrm{X} 10)(\mathrm{r}=-0.6416)$ exhibited highly significant negative correlation, whereas morning relative humidity (X4) ( $\mathrm{r}=0.5170)$, evening relative humidity (X5) (5083), average relative humidity (X6) (0.5154) and rain fall (X9) $(r=0.454)$ had significant positive correlation. But, average temperature (X3) $(r=-0.2294)$ had nonsignificant negative correlation with per cent damage leaves. Whereas minimum temperature $(\mathrm{X} 2)(\mathrm{r}=03934)$ and wind speed had non-significant positive correlation (Table 2).

It is revealed from the forgoing discussion that, per cent damage leaves showed significant and positive correlation with morning relative humidity, evening relative humidity, average relative humidity and rainfall but significant negative correlationwas observed with maximum temperature, sunshine hoursand evaporation rate. Earlier, Balasubramanian et al. (2005) depicted that a significant positive correlation was found between pest incidence and morning relative humidity, evening relative humidity, total rainfall and total number of rainy days. A significant negative correlation was observed between pest incidence and hours of sunshine and maximum temperature. 
Table: 1 Population build up of rice leaf folder in relation to weather parameters during Kharif -2012 and 2013.

\begin{tabular}{|l|l|l|l|l|l|}
\hline \multirow{2}{*}{$\begin{array}{l}\text { Sr. } \\
\text { No }\end{array}$} & $\begin{array}{l}\text { Standard } \\
\text { Meteorological Week }\end{array}$ & Period & \multicolumn{3}{|l|}{ Per cent leaves damaged by C. medinalis } \\
\cline { 4 - 6 } & & Kharif 2012 & Kharif 2013 & Pooled \\
\hline 1 & 33 & 13.08 .14 to 19.08 .14 & 0 & 0 & 0.0 \\
\hline 2 & 34 & 20.08 .14 to 26.08 .14 & 0 & 0 & 0.0 \\
\hline 3 & 35 & 27.08 .14 to 02.09 .14 & 0 & 0 & 0.0 \\
\hline 4 & 36 & 03.09 .14 to 09.09 .14 & 0 & 0 & 0.0 \\
\hline 5 & 37 & 10.09 .14 to 16.09 .14 & 0 & 0 & 0.0 \\
\hline 6 & 38 & 17.09 .14 to 23.09 .14 & 7.86 & 35.97 & 21.9 \\
\hline 7 & 39 & 24.09 .14 to 30.09 .14 & 12.81 & 28.73 & 20.8 \\
\hline 8 & 40 & 01.10 .14 to 07.10 .14 & 14.95 & 12.71 & 13.8 \\
\hline 9 & 41 & 08.10 .14 to 14.10 .14 & 17.25 & 14.71 & 16.0 \\
\hline 10 & 42 & 15.10 .14 to 21.10 .14 & 16.45 & 12.32 & 14.4 \\
\hline 11 & 43 & 22.10 .14 to 28.10 .14 & 14.87 & 0.00 & 7.4 \\
\hline 12 & 44 & 29.10 .14 to 04.11 .14 & 20.39 & 5.86 & 13.1 \\
\hline 13 & 45 & 05.11 .14 to 11.11 .14 & 20.72 & 0.00 & 10.4 \\
\hline 14 & 46 & 12.11 .14 to 18.11 .14 & 16.75 & 7.54 & 12.1 \\
\hline 15 & 47 & 19.11 .14 to 25.11 .14 & 12.17 & 25.47 & 18.8 \\
\hline 16 & 48 & 26.11 .14 to 02.12 .14 & 5.58 & 5.53 & 5.6 \\
\hline 17 & 49 & 03.12 .14 to 09.12 .14 & 4.00 & 3.86 & 3.9 \\
\hline 18 & 50 & 10.12 .14 to 16.12 .14 & 1.04 & 0.85 & 0.9 \\
\hline 19 & 51 & 17.12 .14 to 23.12 .14 & 2.63 & 1.44 & 2.0 \\
\hline 20 & 52 & 24.12 .14 to 31.12 .14 & 0 & 0 & 0.0 \\
\hline 21 & 1 & 01.01 .15 to 07.01 .15 & 0 & 0 & 0.0 \\
\hline 22 & 2 & 08.01 .15 to 14.01 .15 & 0 & 0 & 0.0 \\
\hline 23 & 3 & 15.01 .15 to 21.01 .15 & 0 & 0 & 0.0 \\
\hline 24 & 4 & 22.01 .15 to 28.01 .15 & 0 & 0 & 0.0 \\
\hline & & & & \\
\hline
\end{tabular}

Table: 2 Correlation analysis of rice leaf folder C. medinalis, infestation with meteorological parameters

\begin{tabular}{|c|c|c|c|c|c|c|c|c|c|c|}
\hline \multicolumn{11}{|c|}{ Correlation coefficient } \\
\hline \multicolumn{11}{|c|}{ Kharif 2012} \\
\hline & 1 & 2 & 3 & 4 & 5 & 6 & 7 & 8 & 9 & 10 \\
\hline & Max. T & $\begin{array}{l}\text { Min. } \\
T\end{array}$ & Ave. $T$ & $\begin{array}{l}\text { Mor. } \\
\text { RH }\end{array}$ & $\begin{array}{l}\text { Eve. } \\
\text { RH }\end{array}$ & $\begin{array}{l}\text { Ave. } \\
\text { RH }\end{array}$ & WS & SS & $\mathrm{RF}$ & Eva. \\
\hline $\begin{array}{l}\% \mathrm{DL} \\
12 \\
(\mathrm{Y} 1)\end{array}$ & $\begin{array}{l}- \\
0.7230^{*} \\
*\end{array}$ & $\begin{array}{l}0.342 \\
6\end{array}$ & $-\overline{0.2370}$ & $\begin{array}{l}0.5749 * \\
*\end{array}$ & $\begin{array}{l}0.5409 * \\
*\end{array}$ & $\begin{array}{l}0.5651 * \\
*\end{array}$ & -0.0571 & $\begin{array}{l}- \\
0.5495^{*} \\
*\end{array}$ & $0.4847 *$ & $-\overline{0.7986 * *}$ \\
\hline $\begin{array}{l}\text { NL } \\
12 \\
\text { (Y2) }\end{array}$ & $\begin{array}{l}- \\
0.6516^{*} \\
*\end{array}$ & $\begin{array}{l}0.241 \\
2\end{array}$ & $\overline{-}-3040$ & $0.4820^{*}$ & $0.4635^{*}$ & $0.4808^{*}$ & -0.0995 & $-\overline{0.4350 *}$ & $0.4936^{*}$ & $\overline{0.8033 * *}$ \\
\hline \multicolumn{11}{|c|}{ Kharif 2013} \\
\hline $\begin{array}{l}\% \mathrm{DL} \\
13 \\
(\mathrm{Y} 1)\end{array}$ & $\begin{array}{l}- \\
0.6317^{*} \\
*\end{array}$ & $\begin{array}{l}0.292 \\
8\end{array}$ & $\begin{array}{l}- \\
0.4265 \\
*\end{array}$ & 0.3832 & $0.4266 *$ & $0.4234 *$ & $\begin{array}{l}0.5758 * \\
*\end{array}$ & $\begin{array}{l}- \\
0.4525^{*}\end{array}$ & $\begin{array}{l}0.5455^{*} \\
*\end{array}$ & $\begin{array}{l}- \\
0.64162 * \\
*\end{array}$ \\
\hline $\begin{array}{l}\text { NL } \\
13 \\
(\mathrm{Y} 2)\end{array}$ & $\begin{array}{l}- \\
0.5380^{*} \\
*\end{array}$ & $\begin{array}{l}0.269 \\
3\end{array}$ & $\overline{0} .3349$ & 0.3995 & 0.3895 & 0.3989 & $\begin{array}{l}0.5505^{*} \\
*\end{array}$ & $\begin{array}{l}- \\
0.4360 *\end{array}$ & $\begin{array}{l}0.5820 * \\
*\end{array}$ & $\begin{array}{l}- \\
0.61800 * \\
*\end{array}$ \\
\hline \multicolumn{11}{|c|}{ Pooled 2012-2013 } \\
\hline & Max. T & $\begin{array}{l}\text { Min. } \\
\mathrm{T}\end{array}$ & Ave. $T$ & $\begin{array}{l}\text { Mor. } \\
\text { RH }\end{array}$ & $\begin{array}{l}\text { Eve. } \\
\text { RH }\end{array}$ & $\begin{array}{l}\text { Ave. } \\
\text { RH }\end{array}$ & WS & SS & RF & Eva. \\
\hline $\begin{array}{l}\% \mathrm{DL} \\
\text { poole }\end{array}$ & $-\bar{c} 7130 *$ & $\begin{array}{l}0.393 \\
4 \\
\end{array}$ & $\begin{array}{l}- \\
0.2294\end{array}$ & $0.5170 *$ & $0.5083^{*}$ & $0.5154 *$ & 0.2364 & - & $0.4554 *$ & $\overline{0.6481 * *}$ \\
\hline
\end{tabular}




\begin{tabular}{|l|l|l|l|l|l|l|l|l|l|l|}
\hline $\begin{array}{l}\mathrm{d} \\
\text { (Y1) }\end{array}$ & $*$ & & & & & & & $*$ & & \\
\hline $\begin{array}{l}\text { NL } \\
\text { poole } \\
\text { d } \\
\text { (Y2) }\end{array}$ & $\begin{array}{l}\text { O. } \\
*\end{array}$ & & & & & & & & & \\
\hline
\end{tabular}

$\mathrm{DL}=$ Damaged leaves, $\mathrm{NL}=$ Number of Larva, $\mathrm{T}=$ Temperature, Mor. =Morning, Eve. $=$ Evening, $\mathrm{RH}=$ Relative Humidity, WS =Wind speed, $\mathrm{SS}=$ Sunshine, RF=Rain Fall, Eva=Evaporation rate

\section{References:-}

1. Balasubramaniam, P.; Subramaniam, S. and Chandramani, P. (2005). Influence of silicon and potassium sources on the incidence of major rice pests. In : III Silicon in Agriculture Conference. Uberlandia, 22 -26 October 2005, Brazil, p.105

2. Bautista, R.C., E.A. Heinrichs and R.S. Rejesus, 1984. Economic Injury Levels for the Rice leaf folder, Cnaphalocrocis medinalis (Lepidoptera: Pyralidae): Insect Infestation and Artificial Leaf Removal. Environmental Entomology, 13(2): 439-443.

3. Dhaliwal, G.S., Dhawan A.K. and Singh R. (2007) Biodiversity and ecological agriculture: Issues and perspectives. Indian J.Ecol.34 (2):100-109.

4. Hyslops, J. A., (1941). Insects and weather; climate and Man. United States Department of Agriculture, Washington, D. C.: 503.

5. Kumar S.A.V,Jocque, R and Sebastain, P.A (2009) "A new species of the ant spider genus Suffasia (Araneae:Zodariida) from the Western Ghats, India with a key to the species of the genus", Zootaxa, Vol.2203,pp.55-64.

6. Pinstrup Anderson, P., Pandey, L.R. and Rosegrant, M.W. (1997). The world food situation. Recent developments, emerging issues and long term prospects.P.36.International Food Policy Research Institue, Washington, D.C. 